\title{
Hsp90 Inhibitor Debio 0932
}

National Cancer Institute

\section{Source}

National Cancer Institute. Hsp90 Inhibitor Debio 0932. NCI Thesaurus. Code C92572.

An orally active and small molecule inhibitor of heat shock protein 90 (Hsp90) with potential antineoplastic activity. Hsp90 inhibitor Debio 0932 specifically blocks Hsp90, thereby inhibiting its chaperone function and promoting the degradation of its client proteins, many of which are oncogenic signaling proteins involved in tumor cell proliferation and survival. This may lead to an inhibition of tumor cell proliferation. Hsp90, a chaperone protein upregulated in a variety of tumor cells, regulates the folding, stabilization and degradation of many oncogenic signaling proteins. 